\title{
ŚRODKI ZABEZPIECZENIA WYMOGÓW PRAWA BOŻEGO W MAŁŻENSSTWIE MIESZANYM
}

Problem małżeństw mieszanych sięga swoim początkiem czasów apostolskich i jest ciągle aktualny w dziejach Kościoła. W oparciu o wyraźne słowa św. Pawła ${ }^{1}$ i św. Jana ${ }^{2}$ Kościół od początku swego istnienia zabraniał katolikom zawierania małżeństwa z heretykami i niewiernymi. Swiadczą o tym w sposób niewątpliwy liczne wypowiedzi Ojców i pisarzy kościelnych ${ }^{3}$ oraz uchwały synodów partykularnych ${ }^{4}$. W XIII wieku w nauce dekretystów i dekretalistów ustaliła się opinia wśród kanonistów, że małżeństwo pomiędzy katolikiem i ochrzczonym akatolikiem przybiera postać przeszkody wzbraniającej, podczas gdy małżeństwo katolika $\mathrm{z}$ niewiernym urasta do rangi przeszkody zrywającej ${ }^{5}$. Jakkolwiek w poglądach ówczesnych kanonistów obie przeszkody w małżeństwie mieszanym posiadały walor przeszkód pochodzenia kościelnego, to jednak miały one również jakieś oparcie $\mathrm{w}$ prawie bożym ${ }^{6}$. Jest to bowiem szczególny i rzadki typ przeszkody, w której występują łącznie elementy z prawa kościelnego i elementy z prawa bożego. Nie ulega bowiem żadnej wątpliwości, że występujący w nauce apostolskiej wyraźny zakaz zawierania małżeństw mieszanych był podyktowany troską o zachowanie wymogów prawa bożego. Źródłem ingerencji prawa bożego jest fakt, że w małżeństwie mieszanym występuje realne niebezpieczeństwo utraty

11 Kor 2,11 ; Tt 3,10 .

J 2,10 .

3 Sw. Ignacy Antioch., Epist. ad Policarpum (PG, V, 724); św. Ambroży, De patriarchis, I, c. 9 (PL, XIV, 473); św. Augustyn, Epist. ad Bonifacium (PL. XXXIII, 994); św. Jan Chryzostom, Epist. ad Ephesos, c. 5 (PG, LXII, 141).

4 Conc. Iliberit. (305), c. 15-17 (Mansi, II, 8); conc. Arelat. (314), c. 11 (Mansi, II, 578; conc. Hippon. (393), c. 12 (Mansi, III, 882); conc. Carthagin., c. 12 (Mansi, III, 882): conc. Chalced. (451), c. 14 (Mansi, VI, 1169).

5 A. Esmein - R. Génestal, Le mariage en droit canonique, Paris 1929, I, 242; R. Huysmaus, „Ephemerides Iuris Canonici”, 23 (1967) 224.

${ }_{6}$ J. Bank, Connubia canonica, Romae 1959, 143; F. Wernz - P. Vidal, Ius canonicum ad normam codicis exactum, Romae 1946, V, n. 169. 
wiary, które zagraża w równej mierze zarówno nupturientom, jak i potomstwu ${ }^{7}$. Zasada, która wypływa tu z prawa bożego, wyraża się w słowach: nikomu nie wolno narażać się świadomie i dobrowolnie na niebezpieczeństwo utraty wiary. Tak więc występujące w małżeństwie mieszanym uwarunkowania $\mathrm{z}$ prawa bożego, wyraźnie potwierdzone $\mathrm{w}$ nauce Apostołów, sprawiły, że Kościół nie tylko zabraniał katolikom zawierania tych małżeństw, ale nadto nie udzielał nigdy dyspens od przeszkód małżeństwa mieszanego, pomimo że były to przeszkody tylko z pochodzenia kościelnego. Toteż w sposób kategoryczny Kościół domagał się od strony akatolickiej konwersji.

Zmiany $\mathrm{w}$ prawodawstwie kościelnym na odcinku małżeństw mieszanych nastąpiły dopiero $\mathrm{w}$ czasach, jakie nastały po wielkiej reformacji. W krajach w większości opanowanych przez protestantyzm coraz częściej zaczęły się pojawiać okazje do zawierania przez katolików małżeństw mieszanych. Dotychczasowa zdecydowanie negatywna postawa Kościoła wobec małżeństw mieszanych musiała więc z konieczności ulec rewizji przynajmniej w tym sensie, żeby otworzyć możliwość uzyskania dyspensy od obu przeszkód małżeńskich. W takiej sytuacji po raz pierwszy w dziejach Kościoła narodził się problem odpowiedniego zabezpieczenia wymogów prawa bożego przy udzielaniu dyspensy od przeszkody różnicy wyznania lub od przeszkody róźnicy religii. Do tej pory - jak wiemy Kościół nie zgadzał się na zawieranie małżeństwa mieszanego i nie widział innego wyjścia, jak tylko żądać bezwarunkowo konwersji od strony akatolickiej. Problem, który w napiętej sytuacji domagał się natychmiastowego rozwiązania, polegał na tym, że należało najpierw wynaleźć i ustalić odpowiednie środki, za pomocą których zaspokoi się w sposób wystarczający uwarunkowanie prawa bożego, gdyż tylko w takim wypadku okaże się możliwe udzielenie dyspensy od przeszkód pochodzenia kościelnego. Ponieważ w danym wypadku istota uwarunkowań prawa bożego wyrasta $z$ niebezpieczeństwa utraty wiary przez stronę katolicką i potomstwo, a $\mathrm{z}$ kolei samo niebezpieczeństwo utraty wiary zależy w swoim istnieniu tylko od woli człowieka, stąd jest rzeczą oczywistą, że uwarunkowania $z$ prawa bożego będą $w$ pełni zaspokojone, jeśli nupturienci szczególnie akatolicy — złożą zobowiązania, że nie będą narażały drugiej strony w małżeństwie na niebezpieczeństwo utraty wiary i że potomstwo będzie ochrzczone i wychowane po katolicku. W taki to sposób doszło do narodzin w prawie kanonicznym nowego pojęcia i nowej instytucji prawnej, która przybrała nazwę rękojmi w małżeństwie mieszanym: cautiones. W takim ujęciu rękojmie mają charakter środka zabezpieczającego wymogi prawa bożego.

7 L. Bender, w: „Monitor Ecclesiasticus”, 77 (1952) 443; A. Buys, w: „Periodica”, 37 (1948) $227-241$. 
Rozwiązania, o którym mowa, dokonał papież Benedykt XIV w konstytucji Magnae nobis z 29 czerwca 1748 roku skierowanej do Polski ${ }^{8}$. Od tej chwili ustaliła się w dyscyplinie kościelnej zasada, że Kościół zezwala na związki mieszane jedynie $\mathrm{w}$ takim wypadku, gdy strona akatolicka złoży formalne zobowiązanie (rękojmię), że nie narazi strony katolickiej na niebezpieczeństwo utraty wiary, a oboje nupturienci złożą takież zobowiązanie, że potomstwo z tego małżeństwa będzie ochrzczone i wychowane po katolicku. Wymóg konwersji strony akatolickiej został więc całkowicie zaniechany.

W obronie tak ustalonej zasady zabierali kilkakrotnie głos papieże XVIII i XIX wieku ${ }^{9}$. Tak ustalona dyscyplina kościelna na odcinku rękojmi weszła bez zmian do Kodeksu Prawa Kanonicznego ${ }^{10}$. Z biegiem czasu poszczególne kwestie, które wchodzą w zakres zagadnienia rękojmi, uzyskały w pojawiających się raz po raz wypowiedziach Stolicy Apostolskiej i w dociekaniach kanonistów nową wykładnię. I tak na przyklad samo niebezpieczeństwo utraty wiary, stanowiące w małżeństwie mieszanym właściwą podstawę dla ingerencji prawa bożego, w świetle nowej wykładni obejmuje takie przejawy i okoliczności jak: uleganie błędom strony akatolickiej, powstawanie wątpliwości religijnych i niepokojów sumienia, zaniedbywanie praktyk religijnych, zobojętnienie $\mathrm{w}$ sprawach wiary, odpadnięcie od Kościoła. Poza tym różnica wyznania nie sprzyja wewnętrznej unii dusz, która jest koniecznym znamieniem prawdziwie chrześcijańskiego małżeństwa na wzór unii między Chrystusem i Kościołem, a różnica poglądów w tak zasadniczych sprawach wywołuje najczęściej rozterki i rozdźwięki, które prowadzą nieuchronnie do rozbicia małżeństwa i przykrych powikłań życiowych ${ }^{11}$.

Sama treść rękojmi nie uległa zmianie w prawie kodeksowym, natomiast z większą mocą zostało podkreślone, że dyspensodawca musi urobić sobie pewność moralną co do wypełnienia w przyszłości przez obie strony podjętych zobowiązań. Idzie więc o kwestię szczerości w podejmowaniu zobowiązań. Istniała wśród kanonistów różnica w poglądach, jeśli chodzi o skutki nieszczerych zobowiązań ${ }^{12}$, ostatecznie jednak zwyciężył

8 Fontes, II, n. 387.

9 List Klemensa XIII do kard. de Rohan z 16. XI. 1763 (Fontes, II, n. 460); list Piusa VI do arcbpa w Malines z 13. VII. 1782 (Fontes, II, n. 471); list Piusa VII do arcbpa Moguncji z 8. X. 1803 (Fontes, II, n. 472); list Piusa VIII do biskupów Westfalii z 25. III. 1830 (Fontes, II, n. 482); enc. Grzegorza XVI Summo iugiter z 27. V. 1832 (Fontes, II, n. 484); list do biskupów Węgier z 30. IV. 1841 (Fontes, II, n. 841); list do biskupa z Fryburga z 23. V. 1846 (Fontes, II, n. 503); instrukcja Antonelliana Piusa IX z 15. XI. 1858 (Collectanea SCPF, n. 1169) oraz enc. Arcanum Leona XIII z 10. II. 1880 (Fontes, III, n. 580).

10 Kan. 1061.

11 Pius XI, enc. Casti connubii z 21. XII. 1930 - AAS 22 (1930) 571; F. Haar, De matrimoniis mixtis eorumque remediis, Romae 1931, 9; Th. Vlaming - L. Bender, Praelectiones iuris matrimonii, Bussum 1950, 139.

12 Wyrazicielami poglądu, że nieszczere rękojmie nie wpływają na nieważnoš 
pogląd, że szczerość w składaniu rękojmi jest elementem istotnym, gdyż inaczej nie może być mowy o właściwym zabezpieczeniu prawa bożego.

Co do formy rękojmi prawo kodeksowe stanowiło, że $z$ reguły mają one być złożone na piśmie, gdyż tak złożone rękojmie stanowią pełny dowćd na forum zewnętrznym. W razie trudności rękojmie mogą też być złożone ustnie wobec świadków. Rękojmie złożone na piśmie lub ustnie wobec świadków mają charakter rękojmi formalnych. Prawo kodeksowe nie znało innych rękojmi. Wnet jednak okazało się, że - szczególnie na terenach misyjnych - występują poważne i nieraz wprost niemożliwe do pokonania trudności w zachowaniu przepisu co do obowiązku składania formalnych rękojmi. W tych warunkach w wypowiedziach Stolicy Apostolskiej zaczęło pojawiać się nowe pojęcie na oznaczenie wymaganych prawem rękojmi: cautiones aequipollentes - rękojmie równoznaczne. Pojęcie to wystąpiło w następujących wypowiedziach Stolicy Swiętej: dla Chin z 5 kwietnia $1918^{13}$, dla wikariusza apostolskiego Małych Wysp Sudajskich z 19 stycznia $1936^{14}$, dla Japonii z 30 marca $1938^{15}$, dla Chin z 19 stycznia $1949^{16}$, dla Japonii z 27 kwietnia $1961^{17}$ i z 19 grudnia $1964{ }^{18}$ oraz z 7 stycznia $1965^{19}$. Największe znaczenie ma jednak wypowiedź Kongregacji Świętego Oficjum skierowana do całego Kościoła w dniu 10 maja $1941^{20}$, w której Kongregacja rozciągając pojęcie rękojmi równoznacznych na cały Kościół dała od siebie urzędową wykładnię tego pojęcia prawnego. W świetle tej wykładni rękojmie równoznaczne mają miejsce wtedy, gdy z samego zachowania się strony można słusznie wnioskować i stwierdzić to na forum zewnętrznym, że zna ona dokładnie treść zobowiązań i jest zdecydowana obowiązek ten wypełnić ${ }^{21}$. Ta niewątpliwie bardzo uelastyczniona forma składania obowiązkowych rękojmi nie zmienia jednak samej istoty rękojmi. Zwalniając stronę $\mathrm{z}$ obowiązku składania formalnych rękojmi prawodawca nie zwalnia jej tym samym z obowiązku zabezpieczenia wymogów prawa bożego. Znacznie uległa zmianie sama tylko forma ujawnienia na zewnątrz woli wypełnienia wymogów prawa bożego.

dyspensy, sa m. in. A. Tosco w: „Ius Pontificium”, 13 (1933) 207-214 i 15 (1935) 196-201 oraz A. de Smet, De sponsalibus et matrimonio, Bruges 1937, 441.

${ }_{13} \mathrm{X}$. Ochoa, Leges Ecclesiae post Codicem iuris canonici editae, Romae 1966, I, kol. 110-111, n. 82 .

14 J. Gerhartz, w: „Theologie und Philosophie”, 42 (1967) 559.

15 X. Ochoa, dz. cyt., I, kol. 1880, n. 1431.

16 Tamże, II, kol. 2563, n. 2021.

17 Tamże, III, kol. 4182, n. 2982.

18 J. Gerhartz, art. cyt., 567.

19 X. Ochoa, dz. cyt., kol. 4621, n. 3247.

20 AAS 33 (1941) 294.

21 ,....] eos actus posuerit e quibus concludendum sit et in foro externo constare possit eam cognosere obligationem adimplendi cautiones et manifestasse firmum propositum illi obligationi satisfaciendi". 
Sprawa małżeństw mieszanych znalazła się w obradach II Soboru Watykańskiego. Już we wnioskach przedsoborowych nadsyłanych z calego świata do Rzymu nie brakło głosów domagających się gruntownej reformy przepisów prawnych dotyczących zawierania mieszanych związków małżeńskich, w tym również sprawy rękojmi ${ }^{22}$. Wniesiony pod obrady soboru schemat votum o małżenstwie ${ }^{23}$ przewidywał daleko posuniętą reformę rękojmi, gdyż proponował ustalenie, że należy poważnie zobowiązać w sumieniu stronę katolicką, by złożyła szczere przyrzeczenie, iż ze swej strony zrobi wszystko, co będzie w jej mocy, ażeby potomstwo było ochrzczone i wychowane po katolicku i równocześnie w stosownym czasie należy powiadomić stronę akatolicką o przyjętych przez stronę katolicką zobowiązaniach upewniając się, że strona akatolicka nie wyraża co do tego sprzeciwu. W napiętej dyskusji okazało się wprawdzie, że większość ojców soborowych była skłonna przyjąć takie rozwiązanie, niemniej jednak sporo było też sprzeciwów. W takiej sytuacji zgodzono się co do tego, że problem rękojmi jako problem zawiły i niezmiernie skomplikowany nie dojrzał jeszcze do całkowitego rozwiązania na soborze, gdyż wymaga on dalszych i głębokich studiów. Sprawę wraz ze wszystkimi uwagami wypowiedzianymi na auli soborowej przekazano papieżowi do jego wyłącznej decyzji ${ }^{24}$.

Spełniając postulat soboru, Paweł VI dał nowe rozstrzygnięcie sprawy małżeństw mieszanych $\mathrm{w}$ instrukcji Matrimonii sacramentum z 18 marca 1966 roku wydanej przez Kongregację Doktryny Wiary ${ }^{25}$. W duchu założeń ekumenicznych całkowitej reformie uległy te przepisy z prawa kodeksowego, które w niczym nie zahaczały o prawo boże. Reforma na odcinku rękojmi nie mogła więc pójść zbyt daleko, gdyż tu stanęły na drodze uwarunkowania $z$ prawa bożego ${ }^{26}$. Formalne rękojmie zostały więc $\mathrm{w}$ zasadzie utrzymane nadal $\mathrm{i}$ to $\mathrm{w}$ stosunku do obu stron $\mathrm{w}$ małżeństwie mieszanym ${ }^{27}$, natomiast wyraźnie został przesunięty punkt ciężkości w podejmowaniu zobowiązań ze strony akatolickiej na stronę katolicką 28. Dalej, wyraźne sformułowania instrukcji nasuwają myśl, że prawodawca niejednakowo ocenia siłę obligatoryjną prawa bożego w od-

22 Acta et documenta Concilio Oecumenico Vaticano II apparendo, Series I (Antepreparatoria), Romae $1960-1962$, S. I, v. II, p. 5,465 oraz: p. 7,662 ; p. 2, 361 : p. 8,238 ; p. 1,290 .

${ }_{23}$ Schema voti de matrimonii sacramento, Typ. Pol. Vat. 1964.

24 G. Caprile, Il Concilio Vaticano II, Romae 1965-1968, IV, 499.

25 AAS 58 (1966) 235-239.

26 J. Rybczyk, Przejawy ekumenizmu w instrukcji o małżeństwach mieszanych. „Roczniki Teol. Kan. KUL”, 14 (1967, z. 5) 5-20.

27 G. May, Das neue Mischeherecht, Trier 1966, 180; J. Funk, w: „Rev. Espan. Der. Can.", 21 (1966) 220.

28 J. Bernhard - H. Legrand, w: „Revue de Droit Canonique”, 16 (1966) 64; A. Silvestrelli, w: „Monitor Ecclesiasticus", 91 (1966) 232; F. Bockle, w: Istna 12 (1967) 178; Denis J., w: „L'Année Canonique”, 11 (1967) 154-163; A. Scheuermann, w: ,Theologie und Gegenwart”, 10 (1967) 210. 
niesieniu do obowiązku zachowania własnej wiary przez stronę katolicką i obowiązku zachowania wiary u potomstwa. Nie ma wątpliwości, że w pierwszym wypadku prawo boże ma charakter absolutny, gdyż zachowanie wiary zależy wyłącznie od woli zainteresowanej strony. W drugim wypadku posiada ono walor hipotetyczny, gdyż zachowanie wiary u potomstwa nie zależy tylko od strony katolickiej, skoro prawo do dzieci przysługuje w równym stopniu i stronie akatolickiej ${ }^{29}$. Toteż w tym wypadku instrukcja wymaga od strony katolickiej złożenia przyrzeczenia (rękojmia), że dołoży największych starań, jakie tylko będą możliwe, aby ochrzcić i wychować potomstwo po katolicku. Co do strony akatolickiej, instrukcja każe ją dokładnie pouczyć o poważnym obowiązku ciążącym na stronie katolickiej co do zachowania własnej wiary oraz ochrzczenia i wychowania potomstwa w religii katolickiej. Ponieważ idzie tu o zabezpieczenie tych rzeczy, instrukcja nakazuje zaproponować stronie akatolickiej, by szczerze i otwarcie przyrzekła (rękojmia), że żadną miarą nie będzie przeszkadzała stronie katolickiej w wypełnieniu jej obowiązków. Widać z tego, że choć instrukcja przeniosła główny ciężar zobowiązania na stronę katolicką, to jednak w dalszym ciągu żąda od strony akatolickiej złożenia formalnej rękojmi, choć w nieco innym ujęciu ${ }^{30}$.

Charakterystyczne jest zastrzeżenie instrukcji, że gdyby strona akatolicka oświadczyła, iż nie może złożyć tego przyrzeczenia bez pogwałcenia własnego sumienia, to w takim wypadku sprawa nie upada, gdyż ordynariusz ma obowiązek przedłożyć całą sprawę papieżowi do podjęcia stosownej decyzji. Nie idzie tu więc o wypadek zwykłej odmowy złożenia rękojmi, gdyż wówczas sprawa od razu upada; idzie o wypadek, gdy ma miejsce konflikt sumienia i on właśnie jest źródłem odmowy. W takim bowiem wypadku najczęściej może się okazać, że strona akatolicka jest wewnętrznie gotowa nie stawiać przeszkód stronie katolickiej w wypełnianiu jej obowiązków - w czym już są zachowane istotne wymogi prawa bożego - lecz sumienie nie pozwala jej wypowiedzieć tego formalnie $\mathrm{w}$ sensie zobowiązania $\mathrm{w}$ postaci rękojmi ${ }^{31}$. Z tego wypływa, że każdy wypadek małżeństwa mieszanego winien być traktowany indywidualnie, gdyż na punkcie podejmowania zobowiązań mogą pojawić się u strony akatolickiej różne subtelne powikłania. Stolica Apostolska uznała, że na tym etapie rozwoju zagadnienia małżeństw mieszanych nie czas jeszcze na pozostawienie ordynariuszowi swobody w podejmowaniu decyzji i dlatego nakazała takie wypadki przedłożyć papieżowi do zadecydowania.

29 B. Primetshofer, w: „Th. pr. Quart.”, 114 (1966) 328; R. Beaupère, w: „Istina”, 12 (1967) 180.

30 U. Navarrete, w: „Periodica”, 55 (1966) 760; H. Strauss, w: „Periodica”, 56 (1967) 485 .

31 J. Funk, w: „Rev. Espan. Der. Can.”, 21 (1966) 320. 
W sumie należy więc stwierdzić, że choć instrukcja utrzymała nadal obowiązek złożenia formalnych rękojmi przez stronę akatolicką, to jednak w jej sformułowaniach wystąpiły już wyraźne zarysy nowej koncepcji zabezpieczenia prawa bożego, która wymaga jednak głębszej podbudowy, co można osiągnąc jedynie na drodze dalszych wnikliwych przemyśleń.

W ten sposób sprawa małżeństw mieszanych znalazła się - jako jeden z centralnych problemów ciągle jeszcze czekający na gruntowne i pełne rozwiązanie - na I Synodzie Biskupów w roku 1967. Na trzy miesiące przed rozpoczęciem obrad uczestnicy otrzymali od Stolicy Apostolskiej pełny zestaw pytań, a przy każdym pytaniu były podane wszystkie możliwe argumenty przemawiające za i przeciw pozytywnej lub negatywnej odpowiedzi ${ }^{32}$. Wśród ośmiu pytań dotyczących małżeństwa mieszanego pytanie trzecie ustawiało zagadnienie rękojmi w nowych wymiarach. Ojcowie synodu mieli dać odpowiedź na następujące zasadnicze pytanie: czy dla udzielenia dyspensy od przeszkody wystarczy, jeśli kompetentna władza kościelna urobi sobie pewność moralną co do tego, że strona katolicka nie jest narażona na niebezpieczeństwo utraty wiary i że gotowa jest uczynić wszystko, co jest w jej mocy, aby dzieci były ochrzczone i wychowane po katolicku oraz że strona akatolicka zna obowiązki strony katolickiej i że co najmniej nie wyklucza chrztu i wychowania dzieci W Kościele katolickim? ${ }^{33}$ Widać z tego wyraźnie, że propozycja ta jest dalszym rozwiązaniem i otwartym postawieniem tego, co w jakiś sposób było już zaznaczone zarówno w samym schemacie soborowym, jak i w instrukcji z 18 marca 1966 roku. Widocznie nabrzmiały problem dojrzał już do ostatecznego rozstrzygnięcia. Należało tylko jeszcze znaleźć dla tego rozwiązania pełne i wyczerpujące uzasadnienie. Zrobił to doskonale relator kardynał Marella, przewodniczący Sekretariatu Pro nonchristianis ${ }^{34}$. W swojej wnikliwej relacji kardynał Marella wyodrębnił dwa elementy w pojęciu rękojmi. Elementem zasadniczym jest samo zabezpieczenie prawa bożego, które osiąga się poprzez pewność moralną, jaką urabia sobie dawca dyspensy, że wymogi prawa bożego są w pełni zaspokojone. Z tego elementu Kościół nigdy nie może zrezygnować, gdyż istnieje wewnętrzna i nienaruszalna więź pomiędzy samym prawem bożym i jego zabezpieczeniem. Drugi element w pojęciu rękojmi stanowią same środki zabezpieczenia prawa bożego, poprzez które dawca dyspensy urabia sobie pewność moralną, że w danym wypadku wymogi

32 G. Zizola, Il Sinodo dei Vescovi, Torino 1968, 366; G. Caprile, Il Sinodo dei Vescovi, Romae 1968, 337. Argumenta de quibus disceptabitur in primo generali coetus Sinodi Episcoporum, Typ. Pol. Vat. 1967.

33 U. Navarrete, w: „Periodica”, 67 (1968) 655; J. Rybczyk, Problem małżeństw mieszanych na I Synodzie Biskupów, "Zeszyty Naukowe KUL” 14 (1971, n. 1) s. 6.

${ }_{34}$ Relatio de matrimoniis mixtis, Typ. Pol. Vat. 1967. 
prawa bożego są dostatecznie zabezpieczone. Układ tych środków oraz ich dobór leży całkiem w ręku Kościoła, który zależnie od warunków i potrzeb może je swobodnie ustalać, z tym, że będą one stanowić dostateczne źródło dla zdobycia pewności moralnej. A więc środki zabezpieczenia prawa bożego mogą przybierać w różnych warunkach różną postać. W tym aspekcie dyskusja na synodzie potoczyła się wartko i bez większych napięć. W głosowaniu olbrzymią większością głosów przyjęto bez zmian proponowany projekt. Odbyły się dwa głosowania, gdyż samo pytanie przewidywało osobną procedurę $\mathrm{w}$ stosunku do strony katolickiej i osobną - dla strony akatolickiej. W pierwszym głosowaniu padło 179 głosów pozytywnych ( $\mathrm{w}$ tym placet 137 - placet iuxta modum 42) i 6 głosów negatywnych. W drugim głosowaniu padły 164 głosy pozytywne (w tym placet 92 - placet iuxta modum 72) i 13 głosów negatywnych ${ }^{35}$. Drażliwy i skomplikowany problem został więc rozwiązany, ale na razie tylko merytorycznie. Synod Biskupów jest bowiem tylko ciałem doradczym przy boku papieża, a więc jego uchwały nie mają same z siebie mocy obowiązującej; niemniej jednak stanowią one dla papieża doskonały materiał ułatwiający podjęcie właściwej decyzji.

W lutym 1968 roku powstała specjalna komisja kardynalska, powołana przez Pawła VI, z zadaniem przebadania osiągniętych ustaleń i przygotowania schematu nowego dokumentu. Prace tej komisji trwały z górą rok. Przygotowany schemat rozesłano biskupom całego świata do zaopiniowania. W ten sposób skończyły się czteroetapowe wysiłki zmierzające do pełnego rozstrzygnięcia trudnego i spornego zagadnienia.

W dniu 31 marca 1970 roku Pawel VI opublikowal nowe prawo dotyczące małżeństw mieszanych w motu proprio Matrimonia mixta ${ }^{36}$. W odróżnieniu od instrukcji z 1966 roku, która miała charakter eksperymentalny i przejściowy, nowe prawo ma charakter stałego prawa i z pewnością wejdzie bez zmian do nowego kodeksu.

W sprawie rękojmi nowe prawo stanowi, że w celu uzyskania u ordynariusza miejscowego dyspensy od przeszkody, strona katolicka ma obowiązek oświadczyć, że jest gotowa odsunąć od siebie wszelkie niebezpieczeństwo utraty wiary. Ponadto ma ona taki sam poważny obowiązek złożenia szczerego przyrzeczenia, że uczyni, co będzie w jej mocy, aby całe potomstwo zostało ochrzczone w Kościele katolickim i wychowane w religii katolickiej. Odnośnie zaś do strony akatolickiej prawodawca ustala, że musi ona być powiadomiona w odpowiednim czasie o wspomnianych przyrzeczeniach strony katolickiej, $\mathrm{i}$ to $\mathrm{w}$ ten sposób, by do-

35 G. Caprile, dz. cyt., 434.

36 AAS 62 (1970) 257-263.

37 J. Rybczyk, Przemiany ekumeniczne $w$ dyscyplinie kościelnej na odcinku małżeństw mieszanych, w: Z zagadnień kultury chrześcijańskiej, Lublin 1973, 325. 
kładnie była zorientowana co do zobowiązań podjętych przez stronę katolicką. W tych dwóch punktach papież ustanowił nowe normy odnośnie do sprawy, która przez długi czas stanowiła główne źródło konfliktu pomiędzy Kościołem katolickim i innymi wspólnotami wyznaniowymi. Zasadnicza trudność w rozwiązaniu problemu leży we właściwym pogodzeniu trzech zasad prawa bożego zbiegających się $\mathrm{w}$ małżeństwie mieszanym. Idzie bowiem o pogodzenie wymogu rękojmi jako środka zabezpieczającego prawo boże, które obowiązuje stronę katolicką, z dwoma uprawnieniami, które przysługują każdemu człowiekowi z prawa naturalnego: prawo do zawarcia małżeństwa i prawo do wolności religijnej. Obecne sformułowanie normy prawnej ustawia wreszcie to skomplikowane zagadnienie we właściwych wymiarach ${ }^{37}$. Prawodawca zobowiązuje stronę katolicką do dwóch rzeczy. Po pierwsze - nakłada na nią obowiązek złożenia oświadczenia, że jest gotowa usunąć grożące jej niebezpieczeństwo utraty wiary. Według prawa kodeksowego obowiązek taki obarczał stronę akatolicką. W konsekwencji odpowiedzialność za zachowanie wiary przez stronę katolicką spoczywała na stronie akatolickiej. Nowe prawo zupełnie inaczej ustawia tę sprawę i stanowi, że odpowiedzialność za zachowanie wiary katolickiej spoczywa wyłącznie na stronie katolickiej. Z natury rzeczy wypełnienie tego obowiązku zależy bowiem wyłącznie od woli zainteresowanej strony. Toteż w tym punkcie nakaz prawa bożego jest bezwarunkowy (absolutny) i nie dopuszcza żadnych wyjątków ${ }^{38}$. Zdjęcie ze strony akatolickiej odpowiedzialności za zachowanie wiary przez katolika zlikwidowało rodzący się często konflikt sumienia na tym tle u akatolika. Tak surowy wymóg prawa kodeksowego z reguły zahaczał naturalne prawo każdego człowieka do wolności religijnej.

Po drugie - prawodawca zobowiązuje katolika do złożenia szczerego przyrzeczenia, że zrobi wszystko, co jest w jego mocy, aby całe potomstwo z małżeństwa mieszanego było ochrzczone i wychowane po katolicku. Również i w tym punkcie nowe prawo różni się od ujęcia kodeksowego. I właśnie ten przepis kodeksowy był źródłem licznych sporów oraz rodził ciągłe konflikty sumienia u strony akatolickiej. Tutaj bowiem następuje styk trzech zasad prawa bożego występujących w mieszanym małżeństwie. Przy zbyt rygorystycznym akcentowaniu wymogu złożenia przyrzeczenia przez stronę akatolicką powstawał nieunikniony konflikt $\mathrm{z}$ pozostałymi dwiema zasadami prawa naturalnego ${ }^{39}$. W celu zlikwidowania tego konfliktu papież zobowiązuje w nowym prawie tylko stronę katolicką do złożenia tego przyrzeczenia. Z uwagi zaś na to, że w prak-

38 J. Tomko, w: „Monitor Ecclesiasticus”, 95 (1970) 180; J. Glemp, w: „Prawo Kanoniczne", 15 (1972, n. 1-2) 29.

39 J. Rybczyk, Przemiany ekumeniczne..., 326. 
tyce bardzo często wykonanie tego zobowiązania nie zależy tylko od woli i nastawienia strony katolickiej, prawo żąda od niej jedynie tyle, ażeby szczerze, a więc w sposób zdecydowany, przyrzekła zrobić wszystko, co rzeczywiście będzie leżało w jej mocy, ażeby ochrzcić i wychować potomstwo po katolicku. Idzie więc o samo nastawienie i intencję strony katolickiej przy podejmowaniu zobowiązania i usiłowania wcielenia go w życie. I to jest tutaj istotne. Sam skutek tych wysiłków może się okazać w przyszłości - wbrew jej woli - bezowocny. Toteż prawo boże w tym wypadku ma charakter hipotetyczny, a nie absolutny. Wypływa to stąd, że w małżeństwie obie strony mają pierwszorzędne i nienaruszalne prawo do dzieci. Jak widać, przyrzeczenie, jakie składa tu strona katolicka, posiada z natury rzeczy uwarunkowania z prawa naturalnego. Należy jednak stwierdzić, że zarówno oświadczenie, jak i przyrzeczenie, jakie składa strona katolicka, mają charakter rzeczywisłych rękojmi zabezpieczających prawo boże.

Odmiennie niż w prawie kodeksowym prawodawca traktuje obecnie stronę akatolicką. Kościół nie zobowiązuje strony akatolickiej do niczego, co w jakiś sposób mogloby urazić jej sumienie i naruszyć jej wolność religijną. Nie żąda od strony akatolickiej żadnej deklaracji ani też żadnego przyrzeczenia $w$ sensie zobowiązania. Co więcej, prawodawca nie żąda od akatolika żadnej określonej postawy wobec zobowiązań, jakie zaciąga poprzez rękojmię strona katolicka. Prawo wymaga jedynie, aby akatolik był dość wcześnie powiadomiony o oświadczeniu i przyrzeczeniu, jakie złożyła strona katolicka, i to w taki sposób, aby było pewne, że uświadamia sobie on $\mathrm{w}$ pełni naturę i zakres podjętych zobowiązań. Prawodawca nie żąda od strony akatolickiej postawy aprobującej te zobowiązania, nie żąda nawet postawy, która wyraziłaby się w braku sprzeciwu z jej strony. Należy zatem stwierdzić, że gdyby akatolik oświadczył wyraźnie, że nie zgadza się z zobowiązaniami strony katolickiej, to taka jego postawa nie stanowi w nowym prawie wystarczającej podstawy do odmówienia dyspensy od przeszkód. Przepis prawa nie zawiera tu żadnej klauzuli unieważniającej, a zabezpieczenie prawa bożego, co w tym wypadku jest istotne, w ujęciu nowego prawa znajduje wystarczającą gwarancję w rękojmiach złożonych przez stronę katolicką.

W związku z tym, że nowe prawo inaczej aniżeli prawo kodeksowe formułuje obowiązek składania rękojmi, powstaje pytanie, czy obecnie brak rękojmi i brak moralnej pewności u dyspensodawcy powoduje nieważność udzielonej dyspensy od przeszkód w małżeństwie mieszanym. W prawie kodeksowym sam prawodawca $\mathrm{w}$ przepisie prawnym zajął wyraźne stanowisko w tej sprawie i stwierdzał, że jeden i drugi brak powoduje nieważność dyspensy. Nowe prawo nie ma wyraźnej dyspo- 
zycji w tej sprawie. $\mathrm{Na}$ tej podstawie U. Navarrete ${ }^{40}$ i J. Tomko ${ }^{41}$ wyrażają pogląd, że obecnie oba braki nie powodują nieważności dyspensy. Należy stwierdzić, że wprawdzie ścisła interpretacja przepisu prawnego w zestawieniu z normą ogólną z kan. 11 (leges irritantes et inhabilitantes) prowadzi do takiego wniosku, ale to jeszcze nie wyczerpuje zagadnienia. W danym wypadku należy z konieczności mieć jeszcze na uwadze inne kryteria oceny. Należy więc pamiętać, że obie przeszkody w małżeństwie mieszanym, które ze swej natury są pochodzenia kościelnego, mają też głębokie powiązania - w sensie istotnej zależności — z prawem bożym. Właśnie dla zaspokojenia wymogów prawa bożego Kościół ustanowił rękojmie. Nowe prawo nie zniosło rękojmi, lecz tylko ustawiło je inaczej. W swojej nowej formie rękojmie mają w dalszym ciągu istotne powiązanie z obiema przeszkodami jako zabezpieczenie prawa bożego. Jak długo więc poprzez rękojmie nie zaspokoi się wymogów prawa bożego, nie można wbrew urgującemu prawu bożemu ważnie dyspensować od przeszkód w mieszanym małżeństwie. To samo dotyczy wymogu pewności moralnej, gdyż jest ona ściśle powiązana z właściwym zabezpieczeniem prawa bożego. Z tego zaś wypływa wniosek, że brak rękojmi lub pewności moralnej u dyspensodawcy powoduje nieważność dyspensy. Klauzula unieważniająca wypływa tu z natury rzeczy, tj. z faktu powiązania obu przeszkód z prawem bożym.

Cechą charakterystyczną nowego prawa jest to, że problematyka małżeństw mieszanych jest regulowana dwupoziomowym prawodawstwem: prawem powszechnym i prawem partykularnym. Prawo powszechne, zawarte w motu proprio Matrimonia mixta, reguluje tylko elementy iștotne, które nie znoszą żadnych odchyleń i zróżnicowań, pozostawiając prawu partykularnemu uregulowanie elementów nieistotnych. Normy prawa partykularnego ustala Krajowa Konferencja Episkopatu jako nowo utworzone przez II Sobór Watykański ciało prawodawcze ${ }^{42}$.

Działając w ramach upoważnień, jakich udzielił papież w dokumencie Matrimonia mixta, Krajowa Konferencja Episkopatu jest władna ustalić sposób składania rękojmi przez stronę katolicką oraz sposób powiadomienia o tym strony akatolickiej.

Konferencja Episkopatu Polski uchwałą z dnia 1 kwietnia 1971 roku ${ }^{43}$ ustaliła, że w każdym przypadku strona katolicka jest zobowiązana złożyć na piśmie oświadczenie i przyrzeczenie według ustalonej z góry formuły. Gdyby strona katolicka mimo otrzymanych pouczeń i wyjaśnień odmówiła złożenia przepisanych rękojmi według ustalonej treści,

\footnotetext{
40) U. Navarrete, w: „Periodica”, 59 (1970) 444-447.

J. Tomko, art. cyt., 182.

Dekret Christus Dominus, n. 38 - AAS 58 (1966) 673-696.

124 Konferencja Episkopatu Polski.
} 
wtedy duszpasterz powinien zaniechać starań o dyspensę od przeszkody małżeństwa mieszanego. Stronę akatolicką należy powiadomić o złożonych rękojmiach przez stronę katolicką i jest pożądane, aby potwierdzenie przyjęcia do wiadomości było zaświadczone podpisem strony akatolickiej na dokumencie ıękojmi złożonych przez stronę katolicką.

Konferencje Episkopatu w Belgii ${ }^{44}$, Francji ${ }^{45}$, Szwajcarii 46 i Austrii 47 wydały ogólne postanowienie, że fakt złożenia rękojmi przez stronę katolicką ma być zapisany w protokóle kanonicznego badania narzeczonych, o czym ma być powiadomiona strona akatolicka. Konferencja Episkopatu w Niemczech, ustalając obowiązek odnotowania w protokóle badania narzeczonych faktu złożenia rękojmi, ustala równocześnie trzy pytania, które należy postawić stronie katolickiej, a które wyrażają dokładną treść składanych zobowiązań ${ }^{48}$. Wszystkie Konferencje Episkopatów są zgodne co do tego, że strona katolicka jest zobowiązana w każdym przypadku złożyć oświadczenie i przyrzeczenie przepisane normami prawa powszechnego.

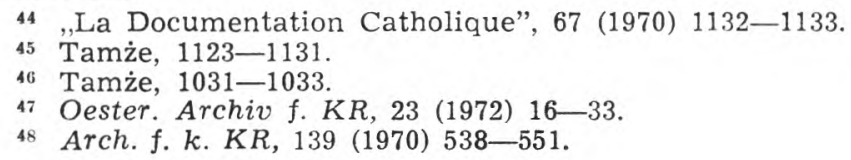

\section{MITTEL ZUM SCHUTZ DES GÖTTLICHEN RECHTS IN DER MISCHEHE}

\section{$\mathrm{Zus}$ am menfassung}

Jede Mischehe trägt die Gefahr des Glaubensabfalls in sich. Daher kommt das Diktat des göttlichen Rechts: Niemand darf sich dieser Gefahr aussetzen. Aus diesem Grund erlaubte es die Kirche von Anfang an ihren Gläubingen nicht Mischehen einzugehen. Und obwohl beide, in der Mischehe auftretenden, Hindernisse stets Hindernisse aus dem Kirchenrecht gewesen sind - das Hindernis der Bekenntnisverschiedenheit und das Hindernis der Religionsverschiedenheit - pflegte die Kirche keine Dispens zu erteilen, weil diese Hindernisse mit dem göttlichen Recht verbunden waren. Benedikt XIV führte erst in der Hälfte des 18. Jahrhunderts die Möglichkeit einer Dispens von diesen Hindernissen ein, wenn die Nupturienten zuvor entsprechende Versicherungen zum Schutz für die Folgen des göttlichen Rechts liefern. Auf diese Weise kam es in der Kanonistik zu sog. Zusicherungen. Der nichtkatholische Gatte musste die Zusicherung geben, die Gafahr des Glaubensabfalls des katholischen Gatten zu vermeiden, und beide Gatten - die Kinder werden nur katholisch getauft und erzogen. Die Vorschrift von obligatorischen Versicherungen (Kautionen) ging ohne Veränderung in den CIC ein. Schwierigkeiten, die in Missionsgebieten bei der Wahrung von Zusicherungen aufgetreten sind, führten in der Kanonistik zur Entstehung der sog. gleichbedeutenden Zusicherungen. Das Wesen der Zusicherung ist in ihnen voll und ganz erhalten geblieben, allein die Äusserungsform dieser Zusicherungen erfuhr eine Veränderung. Im Vaticanum II ist die Angelegenheit der obligatorischen Zusicherungen stark ange- 
griffen worden, weil man sie für widersprüchlich im Hinblick auf die Ökumene hielt. Beim besten Wollen ist es dem Konzil nicht gelungen eine entsprechende Lösung zu finden. Die Angelegenheit war in sich selbst zu kompliziert. Paul VI beharrt grundsätzlich in der Instruktion „Matrimonii sacramentum” von 1966 am Standpunkt der unveränderten Zusicherungen, führte jedoch die Pflicht ein, der Bischof solle die Angelegenheit in diesem Fall an den Apostolischen Stuhl leiten, sooft der im Glauben getrennte Gatte feststellt, das Gewissen erlaube ihm nicht formale Zusicherungen zu geben. Erst die I. Bischofssynode von 1967 fand nach einer tiefgreifenden und umfassenden Diskussion eine richte Lösung für diese feine und komplizierte Angelegenheit, indem sie sie in ökumenische Dimensionen stellte. Dies war möglich, als der Relator Card. Marella eine prezise Unterscheidung zwischen den Folgen des göttlichen Rechts und jenen der kirchlichen Satzungen einführte. Was Wesen der Zusicherung macht in dieser Fassung die Sicherung des göttlichen Rechts aus, von dem die Kirche dispensieren darf. Demgegenüber bestimmt die Kirche die Mittel der Sicherung des göttlichen Rechts selbst; sie darf sie in Abhängigkeit von der Zeit und den Personen willkürlich bestimmen, hauptsache sie sichern ausreichend die Folgen des göttlichen Rechts. In dieser Hinsicht bestimmte die Synode, es genüge, wenn der Bischof zur Utberzeugung gelangte, dass der katholische Gatte nicht der Gefahr des Glaubensabfalls ausgesetzt ist und dass er bereit ist alles Mögliche zu unternehmen um die Kinder katholisch zu taufen und zu erziehen, und zugleich der nichtkatholische Gatte klar von allem in Kenntnis gesetzt wird und sich dagegen nicht sträubt. Unter diesem Blickpunkt erliess 1970 Paul VI in motu proprio "Matrimonia mixta" neue rechtliche Vorschriften dergemäss nur der katholische Gatte Zusicherungen gibt. Ihren Inhalt machen aus: 1) die Verpflichtung, dass er bereit ist den ihm drohenden Glaubensabfall zu entfernen (eine bedingungslos-absolute Verplichtung), 2) die Versicherung, er wird alles Mögliche unternehmen, damit die Kinder katholisch getauft und erzogen werden (relative Verpflichtung). Der nichtkatholische Gatte braucht keine Zusicherungen geben. Er soll nur klar davon informiert werden, wozu sich der katholische Gatte durch die Zusicherungen verpflichtet hat. Die Stellungnahme des nichtkatholischen Gatten zu den Zusicherungen des katholischen wird jetzt nicht mehr berücksichtigt. Die Kirche stellte somit fest, dass es im Klima der ökumenischen Verhältnisse genügt allein dem katholischen Gatten die formellen Zusicherungen aufzutragen, damit die Folgen des göttlichen Rechts gewahrt bleiben. Die Art und Weise, in der die Zusicherungen geäussert werden sollen (ihre Form) soll für lokale Bedürfnisse von den einzelnen Bischofskonferenzen bestimmt werden. Weil jetzt die ganze, aus den Zusicherungen folgende Last vom katholischen Gatten getragen wird, führt das neue Recht die Pflicht ein, ihm einen speziellen seelsorglichen Schutz zu gewähren, der ihm eine geistige Stütze sein soll. Indem das neue Recht die Pflicht der Zusicherungen im vollen Ausmass aufrecht erhält, hat es sie jedoch nicht mehr mit der Ungültigkeitsklausel versehen, wie dies im CIC der Fall war. Aufgrund dessen hegen einige Kanonisten (z. B. Navarette, Tomko) die Úberzeugung, dass gemäss dem Kan. 11 der Ausfall der Zusicherungen nicht die Ungültigkeit der Dispens von den Hindernissen mit sich führt. Diese Auffasung teile ich nich. Obwohl die Ungültigkeitsklausel nicht in der Rechtsvorschrift auftritt, entspringt sie jedoch dem Wesen der Sache, und zwar steckt sie selbst in der Tatsache der Verbindung dieser Hindernisse mit dem göttlichen Recht. Solange das göttliche Recht nicht entsprechend und ausreichend durch die Zusicherungen (formale oder gleichbedeutende) geschützt ist, darf die Kirche von Hindernissen sogar kirchlicher Herkunft nicht gültig dispensieren. 